\title{
Multinational firms, internal capital markets, and the value of global diversification ${ }^{\text {th }}$
}

\author{
Jason Sturgess \\ Dreihaus College of Business, DePaul University, Chicago, IL 60614, USA
}

\begin{abstract}
Over the past 30 years multinational firms' investment grew four times faster than worldwide GDP. Yet the evidence on whether global diversification is valuable is inconclusive. This paper uses detailed FDI data for $251 \mathrm{UK}$ multinational firms and 4,676 subsidiaries for the period 1999-2005 to show that multinational firms exhibit, on average, a global diversification premium. I investigate this result and show that the premium is positively related to "winner-picking" transfers in internal capital markets, and more so for better-governed firms. The findings help explain why multinational firms' investment and global diversification have significantly increased over the past three decades.
\end{abstract}

Keywords: Multinational firms, Internal capital markets, Corporate governance, Valuation, Corporate diversification, Capital budgeting

JEL: G30, G31, G33, G34, G38, L20, L25

\footnotetext{
${ }^{2}$ I thank Viral Acharya, Ian Cooper, Fritz Foley, Denis Gromb, Lee Pinkowitz, Henri Servaes, Paolo Volpin, seminar participants at London Business School, University of Amsterdam, IESE, Stockholm School of Economics, University of Michigan Ross School of Business, Federal Reserve Board, Georgetown University McDonough School of Business, ESSEC, and the University of Cambridge Judge Business School for many helpful comments and suggestions, and Reena Aggarwal and Isil Erel for sharing data. An earlier draft of this paper was titled "The Valuation Effects of Multinational Firms". This work contains statistical data from ONS which is Crown copyright and reproduced with the permission of the controller of HMSO and Queen's Printer for Scotland. The use of the ONS statistical data in this work does not imply the endorsement of the ONS in relation to the interpretation or analysis of the statistical data. This work uses research datasets which may not exactly reproduce National Statistics aggregates. All errors are my own.
}

Email address: jsturge2@depaul .edu (Jason Sturgess) 


\section{Introduction}

The past 30 years has seen an enormous growth of activity in global diversification by multinational firms. Inflows of foreign direct investment (FDI) have grown much faster than either trade or income. While worldwide real GDP increased at a rate of $3.2 \%$ a year between 1980-2007 and worldwide exports by $7.3 \%$, worldwide real inflows of FDI increased by nearly $14 \%, 1$ Over the same time period industrial diversification has fallen out of favor. Many of the large conglomerates that were formed in the 1960s and 1970s were dismantled or became focused in light of a generally negative view in the 1980s and 1990s. Further, existing evidence such as Denis et al. (2002) suggests that global diversification is associated with a diversification discount similar to that for industrially diversified conglomerates. ${ }^{2}$ Why then has global diversification continued to prosper?

This paper reconsiders if multinational firms trade at a discount/premium, and if so, why? In particular I examine if the agency costs that have been found to contribute to the industrial diversification discount also play a role in multinational firms. Specifically, I ask if global diversification is valuable; whether the global diversification premium is associated with with corporate governance; and if multinational firms that create value engage in "winner-picking" (Stein (1997)) by allocating capital efficiently in internal capital markets. To answer these questions, I use comprehensive FDI data on multinational firms' subsidiaries and investment. These data provide far richer details about foreign operations of multinational firms than data used in other studies, and therefore can be used to generate precise measures of the extent to which firms are globally diversified, investment in internal capital markets of multinational firms, and the value of global diversification.

Recent work on the value of global diversification presents mixed results. Denis et al. (2002) study US multinational firms using Compustat data and find that global diversification discounts are of the same order of magnitude as industrial diversifica-

\footnotetext{
${ }^{1}$ United Nations Conference on Trade and Development (UNCTAD) statistics.

${ }^{2}$ Morck et al. (1990), Lang and Stulz (1994), Berger and Ofek (1995), John and Ofek (1995), Servaes (1996), Denis et al. (1997), Lins and Servaes (1999), Rajan et al. (2000), and Schoar (2002) plus others provide evidence of the industrial diversification discount.
} 
tion discounts. While other studies such as Bodnar et al. (2005), Dastidar (2009), and Gande et al. (2009) challenge this result, both Click and Harrison (2000) and Christophe and Pfeiffer (2002) find that global diversification attracts a discount. Examining both industrial and geographical diversification, Dos Santos et al. (2008) examine US - acquirer cross-border acquisitions and find that related international diversification attracts a premium, while industrially diversifying cross-border acquisitions attract a discount. However, Moeller and Schlingemann (2005) find that international acquisitions trade at a discount relative to domestic acquisitions during the period of 1985-1995. In a related study, Doukas and Lang (2003) present evidence that core-related foreign direct investment in new plants increases shareholder value.

In contrast, there is an extensive literature in both economics and finance documenting the advantages multinational firms have over domestic firms. In a series of papers utilizing US foreign direct investment data to study the internal capital markets of multinational firms, Desai et al. (2004a), Desai et al. (2004b), Desai et al. (2005), Desai et al. (2007), and Desai et al. (2008b) show that multinational firms optimally change the capital structure of both the parent company and foreign subsidiaries in response to tax, local risk, financial development, and costly external financing, and that multinational firms use internal capital markets to attenuate the effects of local capital controls through decreasing subsidiary profitability. Using a similar dataset, Desai et al. (2008a) show that multinational firms use their internal capital market to take advantage of local currency crises by investing in local assets and capturing sales growth, and Antras et al. (2009) show that multinational firms' internal capital markets are advantageous when external capital markets are imperfect. Studies of firm-level FDI data for the UK, the US, and Italy show that average labor productivity in foreign subsidiaries of multinational firms is between $30 \%$ and $70 \%$ higher than for domestic firms, while for the home activities of multinational firms it is approximately $30 \%$ higher (Griffith (1999), Griffith and Simpson (2004), Griffith et al. (2004), Benfratello and Sembenelli (2006), and Barba Navaretti and Castellini (2004)) 3

\footnotetext{
${ }^{3}$ Higher productivity and higher valuations may arise because multinational firms have valuable intangible assets that are most efficiently exported within the firm through the internal capital market. This idea is central to most of the modern theories of multinationals, starting with Hymer (1976) and sum-
} 
The lack of a consensus on whether global diversification is valuable is concerning, given both the results on subsidiary performance and the prevalence of multinational firms, and reinforces the need for further examination of the issue. Empirically, studies on the value of global diversification are constrained by data limitations. Accounting standards often request that firms report business and geographic segments, but firms have a great deal of discretion in reporting geographic segment data, and these data are not reported in a complete or consistent manner across firms. Consequently, both the number and the geographic content of the segments in Compustat and similar data providers offer little meaningful information. As a result, most prior studies have measured the value of global diversification relative to focused firms in the country of the parent, and analysis has been limited to using a dummy variable to measure global diversification. This study overcomes these data limitations by employing subsidiary data of UK multinational firms to examine geographic diversification. The UK Office for National Statistics (ONS) Annual Foreign Direct Investment (AFDI) survey captures income and balance sheet information on each foreign affiliate and the domestic operations of all UK based multinational firms. The detail of the AFDI data allows for estimations of subsidiary-year asset weights for each multinational firm, which in turn permits comparisons of multinational firms with portfolios of country-industry matched focused firms. The AFDI data employed in this study features 251 FSTE 500 firms with foreign direct investment in 4,676 subsidiaries spanning 202 countries from 1999 to 2005 .

This paper first examines whether multinational firms trade at a global diversification premium or discount relative to comparable focused firms. The results show that UK multinational firms trade at an average (median) premium of approximately $19 \%$ (10\%) when compared with a portfolio of country-industry matched focused firms. Further, the value premium is increasing in the span of global diversification, measured simply as the number of countries in which a multinational firm has subsidiaries with a controlling interest. The result is robust to using alternate measures of diversifica-

marized in Caves (1996) and Barba Navaretti and Venables (2005). Morck and Yeung (1991) present evidence consistent with these theories. 
tion, and including country-level stock market price ratios, economic development, and UK-foreign country relations.

Second, the paper investigates if differences in firm-level corporate governance are value relevant. $\left.\right|^{4}$ Aggarwal et al. (2009) show that firms with higher levels of firm-level governance and countries where firm-level governance mechanisms are more prevalent are associated with higher market valuations. I examine both the level of governance of the UK parent and the difference in governance between the UK parent and a portfolio of focused firms matched on country and industry. Both are positively associated with the global diversification premium. The results show that approximately one-quarter of the variation in value premium can be explained by differences in firm-level governance between the multinational firm and foreign firms similar to its subsidiaries. The result is based on differences in firm-level governance for developed countries only, where governance is strongest, and likely underestimates the true importance of firm-level governance.

Next, I examine whether internal capital markets contribute to the global diversification value premium. The question of how efficiently diversified firms use internal capital markets is central to the debate on diversification and value. One way in which diversified firms can finance investments - that is not an option for focused firms - is through cash flow transfers from divisions without investments to divisions with investments. At the same time, the literature on internal capital markets for industrially diversified firms has shown that one potential cost to being diversified is mismanagement of internal cash flows, which are not always allocated to high-growth divisions (see for example, Shin and Stulz (1998), Rajan et al. (2000)). For each multinational firm I classify its subsidiaries as high-productivity or low-productivity based on investment opportunities. Using the ONS AFDI data I estimate the value-added created by each multinational firm through cross-divisional transfers in the internal capital market, similar to Rajan et al. (2000). If, on average, high-productivity subsidiaries receive an

\footnotetext{
${ }^{4}$ Firm-level or internal corporate governance captures the governance mechanisms that operate within the firm, and are heavily influenced by a firm's choice of governance attributes in its charter and policies. These govern decision-making at both the parent and subsidiary level and may provide an explanation of why multinational firms' subsidiaries exhibit better financial decision-making and higher productivity.
} 
increase in investment and low-productivity subsidiaries receive lower investment, then the internal capital market will contribute to the value of the multinational firm, and in turn the global diversification premium. Consistent with this, I find that the global diversification premium is positively related to the value added from transfers across divisions. Furthermore, the results show that the relation between the diversification premium and transfers across divisions is stronger in well-governed firms. Better governed multinational firms create more value through efficient transfers in their global internal capital market.

The results on corporate governance and internal capital market allocation demonstrate the channels through which global diversification is valuable. There are relatively few studies that examine the linkage between quality of corporate governance and the global diversification discount/premium, and none that examine internal capital markets and the global diversification discount/premium. Gande et al. (2009) show that global diversification is more valuable where US firms diversify into countries with creditor rights that are stronger than that of the US. A few papers examine the industrial diversification discount internationally. Khanna and Palepu (2000) argue that diversification may be more valuable in emerging markets than in more developed economies. Fauver et al. (2003) examine firms from 35 countries during 1991-1995 and find that the value of corporate diversification is related to the level of capital market development, international integration, and legal systems.

Combined with the literature on productivity and capital allocation for subsidiaries of multinational firms, the findings in this paper may help explain why multinational firms' investment and global diversification have significantly increased over the past two decades. If multinational firms do not provide shareholders with superior investment opportunities then they should demise in the manner that industrially diversified conglomerates have fallen out of favor. Instead, both the UK ONS and US Bureau of Economic Analysis show that FDI has grown significantly. In addition to the growth in global inward FDI of $14 \%$ between 1980-2007, I find that the percentage of foreign assets in UK multinational firms increased from 49\% to 68\% through 1999 to 2005 , and Denis et al. (2002) document that the percentage of US public firms that are multi- 
national increased from $23 \%$ to $45 \%$ through 1984 to 1997 . If global diversification is valuable, these trends are easily explained by shareholders and firms allocating capital to superior investments.

In extensions to the main results, I show that the value of global diversification is associated with the distance between the parent firm and subsidiaries, culture, and openness to trade. The global diversification premium is greater where geographical distance between the multinational parent and it subsidiaries is lower; where subsidiaries are located in countries with similar culture to that of the parent home country; and where FDI is in countries most open to trade. The results show that the efficacy of FDI depends not only on the multinational firm but also country-level similarities. Further, the documented global diversification discount is robust to these characteristics. Next, I examine alternate measures of diversification. Alternate measures of diversification, including industrial diversification, are shown to be weakly value-relevant but the global diversification premium continues to be significant. Finally, I employ instrumental variable analysis and Heckman's two-step procedure to show that the results are robust to controlling for simultaneity and self-selection biases.

The rest of the paper is organized as follows. Section 2 describes the data in detail. Section 3 presents the results on the global diversification premium, linkages to multinational firm corporate governance, and internal capital markets. Section 4 investigates the robustness of results by considering alternative specifications and endogeneity. Finally, Section 5 concludes.

\section{Data}

Multinational firms and their subsidiaries are identified using the Annual Foreign Direct Investment Survey, a proprietary dataset from the UK ONS.5 The ONS collects

\footnotetext{
${ }^{5}$ The purpose of the survey is to collect financial information on the relationship between UK companies and foreign parents and associates (inward FDI), and between UK companies and foreign subsidiaries, affiliates, and branches (outward FDI). The information is primarily required for measuring the UK's balance of payments and international investment position. The survey comprises three main areas: flows of investment, level or stock of investment, and earnings from the investment in the local enterprise. The level or stock of investment represents the net book value of the subsidiary to the parent at the end of the period. This accounts for goodwill write-offs, the revaluation of assets, and exchange rate fluctuations.
} 
and prepares foreign direct investment (FDI) flow and stock data and local subsidiary operating data. $\sqrt[6]{6}$ For each subsidiary the GBP net book value is reported at the two-digit level of the UK Standard Industrial Classification and across 214 countries. In 2005 the data covered 2,307 UK multinational firms and 10,580 subsidiaries in 2005.

The sample is focused in two ways: first, only those firms that are constituents of the FTSE 500 are included. Next, as is standard in the corporate finance literature, financial, real estate, and insurance firms, as well as firms operating in government or education are excluded. However, for non-financial multinational firms, only those that report a financial subsidiary with an asset weight greater than $20 \%$ are excluded 7 Lastly, firm characteristics are collected from Worldscope for the final sample of 251 multinational firms

The analysis in this paper compares the value of multinational firms with the imputed value of its subsidiaries based on benchmark comparable firms. The benchmark is a comparable firm matched on the country and industry of each subsidiary. To facilitate this, country-industry median values for Tobin's q and firm characteristics are are captured from Worldscope for 63 countries and 18 Industry Classification Benchmark (ICB) super-sector industries.$^{8}$ The universe of comparable firms is then reduced as follows. First, only industrially focused firms are included. Second, similar to the industrial diversification literature, all local firms with a Tobin's q greater than eight are excluded. Third, any local industry match with less than five observations are dropped. Since the Annual Foreign Direct Investment Survey covers investment in up to 214 countries and Worldscope collects public firm data for 63 countries some subsidiaries have no comparable firm at the local level. The fraction of subsidiaries matched at the country-industry level is $67 \%$ on an asset-weighted basis. For empty local matches, a

\footnotetext{
${ }^{6}$ The local enterprise units include subsidiaries, associate companies, and branches. If a firm owns more than $50 \%$ of the equity share capital of another firm, then that is its subsidiary. If only $10 \%$ to $50 \%$ is owned, then it is an associate. A branch is a permanent plant as defined for UK corporation tax and double taxation relief purposes. Throughout this study, subsidiary refers simply to any enterprise unit where the multinational firm has effective voice ( $>10 \%$ ownership).

${ }^{7}$ Further investigation shows that many of the financial subsidiaries of non-financial firms are treasury functions required by larger multinational firms. For robustness, the analysis is repeated for lower cutoffs, and consequently lower sample sizes, with similar results.

${ }^{8}$ Worldscope includes data on over 38,000 firms globally. The ICB industrial sectors are from Worldscope and are consistent across countries.
} 
benchmark is selected at the region-industry level. Twelve regions are identified based on financial development, GDP, and locality 9 For null regional matches the benchmark is the UK-industry match. Therefore the match of last resort compares subsidiaries of UK multinational firms with UK focused firms. Overall, $67 \%$ of the match is at the local level, $32 \%$ at the regional level, and only $1 \%$ rely on a UK match 10 Fourth, observations where the imputed level of Tobin's q is greater than eight, or where the actual value is either greater than four times or less than one-fourth its imputed value are dropped ${ }^{11}$

The resulting sample includes 251 public multinational firms from the FTSE 500. These firms have interests in 4,676 subsidiaries (4,431 are outside of the UK) operating in 202 countries with a median book value of $£ 6.1$ million ( $£ 4.7$ million outside of the U.K). Table 1 presents the multinational firm investment and operations. The sample comprises 1,166 firm-years and 21,315 subsidiary-years. On average, 54.5\% of all assets are held in foreign subsidiaries. Of these, approximately one-third sits in the US and a further one-third in Europe. Investment in foreign subsidiaries has grown from $49.2 \%$ to $67.7 \%$ from 1999 through to 2005 , while investment in US subsidiaries has decreased from $17.9 \%$ to $12.8 \%$. The smallest individual recipients are mostly Asian countries such as Taiwan and the Philippines, or Eastern European countries such as Turkey and the Czech Republic. On the whole, only a very small percentage of assets sit in the least-developed regions: $0.48 \%$ sit in Central Africa, $0.56 \%$ sit in the MiddleEast, and $1.91 \%$ sit in Central America and the Caribbean. On average, multinational firms span 12.2 countries and 2.5 countries through 18.3 subsidiaries.

\footnotetext{
${ }^{9}$ The twelve regions are Central America and Caribbean, Central Asia, Eastern Europe, Japan, Middle East and North Africa, Oceania, Scandinavia, South America, South East Asia, UK, US and Canada, Western Europe excluding the UK and Scandinavia. Subsidiaries in Africa are replicated using the UK comparable firms because of limited coverage in Worldscope.

${ }^{10}$ An examination of omitted robustness regressions focusing solely on those firms with a local match does not reveal significantly different results, but does yield lower statistical power.

${ }^{11}$ This strategy is also used in Berger and Ofek (1995) and Denis et al. (2002)
} 


\section{Main Results}

\subsection{The global diversification premium}

I measure the global diversification premium using a variation of the excess value measure originally developed by Lang and Stulz (1994). Excess value is computed as the difference between the market value of a multinational firm and a portfolio of single-segment firms in the same country, same industry, and same year. This approach assumes that the best match for a multinational subsidiary is a firm in the subsidiary's country of operation, and not in the multinational parent's home country. 12 I compute the log of the ratio of a firm's Tobin's q and its imputed Tobin's q, where the imputed value is the end-of-the-year asset-weighted average Tobin's q of comparable stand-alone firms. Tobin's q is estimated as the market value of equity plus book value of total assets minus book value of common equity, all depleted by the replacement value of assets, which is estimated as the book value of total assets. The asset weight in each subsidiary-country-industry-year is calculated using the book value of assets (measured in nominal GBP) from the UK ONS AFDI survey. The method for selecting stand-alone firms is described in Section 2 .

Table 2 presents univariate results for the global diversification premium. Panel A presents a first glance into the differences between multinational firms and local firms. In addition, I estimate relative measures of possible determinants of excess value using the same method as for Tobin's q. The independent firm characteristics generally used in the literature are firm size measured by the natural logarithm of total sales $(\log ($ Sales $))$, and the ratios of total debt to assets (Debt/Assets), capital expenditures to assets (Capex/Assets), earnings before interest and taxes to sales (Ebit/Sales), and research and development expense to sales (R\&D/Sales). Similar to prior work these variables are winsorized at extreme percentiles (1st and 99th). The average (median) raw excess value is $10 \%(6 \%)$. Significantly, multinational firms are larger, invest more, and

\footnotetext{
${ }^{12}$ This is akin to assuming global segmentation in the market for real assets. In contrast, Denis et al. (2002) match at the home country. Where real assets do differ across countries, matching at the subsidiary's country of operation allows insight into the effects of multinational firm ownership and global diversification. Alternatively, matching at the multinational firm's home country may lead to spurious results where valuation results are driven by differences in the valuation of similar assets across countries.
} 
produce higher profits than their benchmark portfolio of comparable local firms. Panel B presents descriptive statistics on global and industrial diversification. The degree of global diversification, Global Div, is measured as the number of countries in which a multinational firm has subsidiaries. Global diversification is highly correlated with the number of subsidiaries (coefficient of 0.86) and less so with industrial diversification measured as the number of ICB industries (coefficient of 0.34).

In Panel $\mathrm{C}$ a broad brush analysis of excess value and diversification is presented. Excess value is increasing in the degree of global diversification. On average, multinational firms that invest in less than three countries exhibit no significant excess value while the most globally diversified firms exhibit an excess value of $24.5 \%$. Further, the least globally diversified multinational firms tend to trade at a zero premium or discount. Combined, these univariate results show that multinational firms are more highly valued than their benchmark portfolio of comparable local firms. However, plausible explanations for the difference in value might be that multinational firms have characteristics that make them more valuable; indeed Panel A of Table 2 shows that multinational firms are significantly different to their imputed firms. Equally, the univariate results suggest an industrial diversification premium. It is therefore necessary to examine the relationship between valuation and global diversification in multivariate regressions that control for firm characteristics.

Table 3 reports the results from regressing multinational firms' excess values on global diversification, firm characteristics and calendar-year dummies, where standard errors are adjusted for clustering at the firm-level. Regressions (1) - (3) show estimates for regressions of excess value on a constant and the degree of global diversification (Global Div). The results show that, after controlling for time effects, multinational firms are valued at a premium compared with their local counterparts. Regression (3) presents results of estimation of excess value on Global Div and Global Div ${ }^{2}$. The excess value-diversity relationship is curvilinear: the value premium increases at lower levels of global diversity and then decreases for higher levels. 13 Regression (4) intro-

\footnotetext{
${ }^{13}$ The optimum number of countries is between forty and fifty. While this number should not be taken literally it does suggest that more internationally diversified multinational firms are valued more highly.
} 
duces firm characteristics generally used in the literature. For each firm, the relative difference between its own and imputed characteristic is used. The relative differences are firm size measured by the natural logarithm of total sales $(\log (\operatorname{Sales}))$, and the ratios of total debt to assets (Debt/Assets), capital expenditures to assets (Capex/Assets), earnings before interest and taxes to sales (Ebit/Sales), and research and development expense to sales ( $R \& D /$ Sales). Consistent with existing literature, excess value is higher for firms with higher Ebit to sales, investment in R\&D, and capital expenditure.

Regressions (5) and (6) re-introduce global diversification. For a multinational firm with subsidiaries in the average of 12.2 countries the value premium is estimated to be nineteen percentage points after controlling for differences in firm characteristics compared with twenty percentage points in regression (3). These results indicate that global diversification is valuable. Further, the presence of a global diversification premium may explain why, unlike industrial diversification, global diversification has continued to increase

\subsection{Does better governance explain the premium?}

In this section I examine the relation between firm-level corporate governance and the global diversification value premium. A significant literature shows that corporate governance is an important determinant for firm value. In the modern era this begins with Jensen and Meckling (1976), Morck et al. (1990) and others in the US, and La Porta et al. (1998), La Porta et al. (2000), Claessens et al. (2002), Dyck and Zingales (2004) plus others internationally. More recently, Aggarwal et al. (2009) show that firm-level corporate governance is important in explaining differences in firm valuation across countries. In addition, better firm-level governance may explain why subsidiaries of multinational firms are valued higher than local comparable firms. For instance, a subsidiary of a UK multinational firm might benefit from the same level of governance as the parent firm, which in turn might be higher than foreign firms local to the subsidiary.

To measure the corporate governance of both the multinational parent and foreign firms I use the composite governance index from Aggarwal et al. (2011). They build the composite governance index using 41 firm-level governance attributes collected by 
Risk Metrics/ISS for twenty-three countries. Each firm receives a score of one for every attribute present, and the aggregate score is divided through by 41 . The attributes cover four broad subcategories: (1) Board (24 attributes), (2) Audit (three attributes), (3) Anti-takeover provisions (six attributes), and (4) Compensation and ownership (eight attributes) ${ }^{14}$ Throughout, I assume that a subsidiary benefits from the same level of governance as its parent.

I use the composite governance index in two ways to examine if the global diversification value premium is related to governance. First, I use the composite governance index for the UK parent, GOV. The parent-level composite governance index measures the governance for the UK parent only. Consequently, estimations of excess value including $G O V$ tests if better governed multinational firms exhibit larger global diversification premiums. The average GOV for UK multinational firms is $56 \%$, and the standard deviation is $7.3 \%$.

Next, I measure the difference between the UK parent's composite governance index and its benchmark composite governance index, GOV GAP, where the benchmark is based on the location and industry of its subsidiaries. The benchmark composite governance index estimates the level of governance for each subsidiary as if it were owned locally using the country-industry median composite governance index. For each parent multinational firm the benchmark is estimated as the asset-weighted average of its subsidiaries' benchmark composite governance index. For subsidiaries where no benchmark composite governance index exists, the benchmark is the country median composite governance index, else the parent composite governance index is used. For UK multinational firms the average $G O V G A P$ is $-0.1 \%$ and insignificant from zero, and the the standard deviation is $4.7 \%$. The insignificance of GOV GAP shows that UK multinational firms are, on average, no better governed than the portfolio of benchmark firms. Importantly, this rules out that the global diversification value premium

\footnotetext{
${ }^{14}$ Board attributes capture the aspects of the board of directors such as board independence, composition of committees, size, transparency, and how the board conducts its work. Audit includes questions on the independence of the audit committee and the role of auditors. Anti-takeover provisions are drawn from the firms charter and by-laws and refer to dual-class structure, role of shareholders, poison pills, and blank check preferred. Compensation and ownership deals with executive and director compensation on issues related to options, stock ownership and loans, and how compensation is set and monitored.
} 
documented in Section 3.1 arises simply because the benchmark firms have worse governance on average.

The results from regressions estimating excess value on corporate governance are presented in Table 4. Once again, I estimate multinational firms' excess values in a regression on global diversification, firm characteristics and calendar-year dummies, where standard errors are adjusted for clustering at the firm-level. In regressions (1) and (2) I introduce GOV and GOV GAP as explanatory variables. The results indicate that firm-level corporate governance is an important determinant of the documented global diversification premium. The coefficient on $G O V$ of 0.009 in regression (1) is both economically and statistically significant, and shows that better governed multinational firms exhibit higher global diversification premia. A one standard deviation increase in $G O V$ is associated with an increase in the value premium of around six percentage points. Regression (2) examines the effect of the governance gap, GOV GAP, on the value premium. The coefficient on GOV GAP of 0.012 is both economically and statistically significant, and shows that the global diversification premium is higher for multinational firms better governed than benchmark foreign firms. A one standard deviation increase in GOV GAP is associated with an increase in the value premium of around five and a half percentage points.

The results in regressions (1) and (2) show that better governed firms are associated with a greater diversification premium and that the premium is largest where the governance gap between subsidiaries of multinational firms and benchmark foreign firms is largest. This finding suggests that multinational firms that export good governance through the organization achieve higher valuations. The ability of a multinational parent firm to set governance in foreign subsidiaries should depend on the control rights that the parent has in the subsidiary. To estimate control rights, I include the ownership stake that the multinational firm has in the subsidiary. Table 1 shows that on average multinational firms have $94.5 \%$ ownership in their subsidiaries. Further, parent firms have $100 \%$ ownership in $69 \%$ of subsidiaries. Regression (3) includes both the asset weighted ownership $O W N$, and the asset weighted interaction of GOVGAP and $O W N$. The results show that value continues to be positively related to the governance gap, 
but further that the effect is stronger where multinational firms hold a larger ownership stake in subsidiaries.

Next, I examine if governance is more important for firms that are more globally diversified. If the costs to diversification arise because internal capital markets increase the scope for agency costs, then corporate governance should be more important for the multinational firms most globally diversified. In Regression (4) I introduce the interaction between GOV GAP and Global Div. Once again, both the coefficients on Global Div and GOV GAP are positive and significant. Further, the coefficient on Global Div $\times$ GOV GAP is positive and significant, which indicates that corporate governance is complimentary to global diversification:

The results in regressions (1) - (4) support the hypothesis that multinational firms are able to create value through corporate governance. However, the value-governance relationship may flow in both directions. An alternate hypothesis is that local firms are better governed and have higher valuations than multinational firms' subsidiaries. Then, the governance gap would be positively related to valuation, but the regression results would describe a governance discount. For UK multinational firms this might arise because a significant proportion of assets are invested in countries with better firm-level governance such as the US and Canada. If the results in regressions (1) (4) reflect only a governance discount then including the governance gap for only those subsidiaries that have a positive governance gap - and setting it to zero for all other subsidiaries - should yield insignificant results. This is addressed in regression (5). The coefficient for the positive governance gap is similar to early results and equates to a governance premium of approximately seven percentage points.

While the results for the governance effects on the valuation premium are both economically and statistically significant, they probably underestimate the true significance. The governance gap employed measures the governance gap for twenty-three developed countries and ignores governance differences between UK multinationals and firms in much less well developed countries. In comparison, excess value tracks comparable firms in sixty-three countries. Thus the results likely underestimate the true importance of the firm-level governance channel. 
Overall, the results on corporate governance show that multinational firms are rewarded, in terms of valuation premium, for both better corporate governance in general and better corporate governance than foreign firms in the location of subsidiaries. The findings are consistent with those in Ellis et al. (2012), who present evidence that acquirers from countries with better governance gain more from acquisitions, and that gains are higher when targets are from countries with worse governance. The results illustrate that better governance is an important determinant of the global diversification premium.

\subsection{Internal capital markets}

In this section I examine whether internal capital markets contribute to the global diversification value premium. The question of how efficiently diversified firms use internal capital markets is central to the debate on diversification and value. One way in which diversified firms can finance investments - that is not an option for focused firms - is through cash flow transfers from divisions without investments to divisions with investments. Such transfers in internal capital markets may provide greater benefits to globally diversified firms than for industrially diversified firms operating within a single country because both investment opportunities and financing vary more across subsidiaries. At the same time, the literature on internal capital markets for industrially diversified firms has shown that one potential cost to being diversified is mismanagement of internal cash flows, which are not always allocated to high-growth divisions (see for example, Shin and Stulz (1998), Rajan et al. (2000)).

To study the relation between global diversification, internal capital markets, and value, I examine how cross-divisional transfers affect value in the spirit of Rajan et al. (2000). I first distinguish between efficient and inefficient transfers by classifying subsidiaries into low-productivity and high-productivity divisions based on their investment opportunities. Specifically, I examine whether the (country-industry) imputed Tobin's q for subsidiary $j, q_{j}$ is lower or higher than the firm simple average imputed Tobin's q, $\bar{q}_{j}$. If the imputed Tobin's q is higher, the subsidiary is classified as a high-productivity subsidiary. If it is lower, it is classified as a low-productivity subsidiary. The comparison between the subsidiary investment opportunities, estimated as the imputed Tobin's q, 
with the average investment opportunity available to the firm facilitates examination of whether multinational firms make efficient transfers into high-productivity subsidiaries. Next, I estimate transfers across subsidiaries using the change in asset weight over the year, $\Delta \omega_{j, t}$. The transfer measures the increase or decrease in resources in a subsidiary relative to all other subsidiaries in the firm. Finally, I compute value added at the firmlevel by first weighting the transfer to a subsidiary by the difference between a subsidiary's Tobin's q and the average Tobin's q in the firm, and then adding the weighted transfer across all $N$ subsidiaries of a firm in a year:

$$
\text { Value Added }_{t}=\Sigma_{j=1}^{N} \omega_{j, t} \Delta \omega_{j, t}\left(q_{j, t}-\bar{q}_{j, t}\right)
$$

where $\omega_{j, t}$ is the share of firm resources in division $j$ at the beginning of the year, $\Delta \omega_{j, t}$ is the change in resources in subsidiary $j$ which is the measure of the funds transferred to/from a subsidiary (relative to other subsidiaries), and $q_{j, t}-\bar{q}_{j, t}$ is the difference between a subsidiary's Tobin's q and the average Tobin's q in the firm. Firm value added measures the value created through transfers - in terms of investment weights - towards higher productivity subsidiaries. If, on average, high-productivity subsidiaries with $q_{j, t}>\bar{q}_{j, t}$ receive an increase in investment, $\Delta \omega_{j, t}>0$, and low-productivity subsidiaries with $q_{j, t}<\bar{q}_{j, t}$ receive lower investment, $\Delta \omega_{j, t}<0$, then the internal capital market should contribute to the value added of the multinational firm.

There is a subtle difference between the transfers Rajan et al. (2000) use and the transfers I use to estimate value added in equation 1. Rajan et al. (2000) measure transfers by the difference between the dollar investment a segment makes when it is part of a diversified firm and the investment it would have made had it been on its own, which is approximated by the weighted average of the ratio of capital expenditures to assets of single-segment firms in the same industry. Next, they subtract the average industryadjusted capital expenditure-to-assets ratio averaged across the segments of the firm to control for the possibility that diversified firms have more funds. As it is not possible to measure dollar investment for each subsidiary, I use the change in investment weight. The advantage of this approach is that directly captures the relative expansion or contraction of subsidiaries. The disadvantage is that I am unable to measure trans- 
fers relative to single segment firms, which is relevant for examining the value premium relative to single country-industry benchmark firms. Therefore, in the analysis of the efficiency of internal capital markets I examine the value of the multinational firm rather than excess value.

The descriptive statistics for value added are presented in Table 5. Panel A shows that value added is on average positive: multinational firms on average transfer investment towards high-productivity subsidiaries. In Panel B I sort valued added by global diversification and corporate governance separately, where the sorts are based in the median year level. Value added is increasing in both global diversification, which reflects the size of the internal capital market, and corporate governance, which indicates how well capital should be allocated within an internal capital market. Next, I sort by global diversification and corporate governance to examine the combined affect of diversification and governance on value added. The results show that firms with both greater diversification and better corporate governance realize the greatest value added. Further, moving from low diversification to high diversification only increases value added where corporate governance is high; and moving from low governance to high governance only matters for value added in those firms that exhibit high levels of diversification. Consistent with the results presented in Table 4. corporate governance and global diversification are complimentary in creating value. While the prior results focused on Tobin's Q, the results on value added show that transfers through the internal capital market in firms with high corporate governance is one channel through which the value premium arises.

To understand if the efficient transfers in the internal capital market contribute to multinational firm value, I estimate the relation between Tobin's q of a multinational firm and the value added by allocation. These results are reported in Table 6, I include the relative firm-level characteristics introduced earlier, and again include calendar year dummies and cluster standard errors at the firm-level. Regression (1) presents estimation results of multinational firm value on value added $(V A)$ and firm characteristics. Value added has a positive and significant effect on firm value (coefficient of 0.2839). Multinational firms that allocate investment towards high productivity sub- 
sidiaries exhibit higher valuations. This result indicates that multinational firms add value by forming an internal capital market where resources can be allocated to their best use, or "winner-picking” (Stein (1997)).

It is possible that value added is related to either the degree of global diversification or corporate governance. In columns (2) and (3) I introduce global diversification (Global Div) and firm-level corporate governance $(G O V)$. Importantly, value added continues to have a positive and significant effect on firm value. In fact, the importance of value added becomes larger and more significant when included alongside $G O V$, which suggests that there may be an interaction effect between value added and governance. Indeed, it is plausible that firms with better governance make more efficient transfers because better governance mitigates agency problems. Hoechle et al. (2011) find that the industrial diversification discount narrows significantly for firms with better corporate governance. To explore this, I include the interaction between governance and value added, $G O V \times V A$, in the estimation of multinational firm value, and report the results in column (4). The results show that multinational firm value is increasing in both value added and corporate governance, and further also increasing where the interaction of value added and governance is greater. While governance and value added contribute to firm value separately the effects are also complimentary. Better governed multinational firms create more value through efficient transfers in their global internal capital market.

\section{Extensions and robustness}

\subsection{Distance, culture, and openness}

In this section I investigate the relation between a multinational firm's global diversification premium and characteristics of the host countries in which it invests. The characteristics considered are distance; culture and religion; and openness to trade. These three groups of characteristics potentially explain country pairwise differences in global diversification not captured by firms relative financial characteristics

Distance is taken from the CEPII Distances dataset, and measures the bilateral distance between the UK and host country in terms of geographical distance. Gravity 
models have been used to explain trade and FDI since Tinbergen (1962), and imply that geographical distance might pose barriers to FDI. The second group of characteristics are culture and religion. Religion and other cultural dimensions have been shown to affect economic outcomes (Barro and McCleary (2003); Guiso et al. (2003); Guiso et al. (2006)). Further, Stulz and Williamson (2003) show that culture, proxied by differences in religion and language, can explain creditor and investor rights; Mueller and Philipon (2011) show that culture and religion affect corporate ownership; and Ahern et al. (2012) show that culture affects merger activity and outcomes. Following Stulz and Williamson, I measure religion distance using the primary religion of the country using the CIA World Factbook. To proxy for cultural distance from the UK I include a dummy variable indicating if the host country shares a common language and is/was a British colony. Both measures are from the CEPII Distances dataset.

Openness measures how open a country is to international trade. One might expect that multinational firms fare better in countries open to international trade, possibly because incumbents are open to foreign ownership or openness spurs financial development (Rajan et al. (2000)). I use two measures of international trade. Natural Openness (FR) from Frankel and Romer (1999) is a measure of natural openness based only on geographic characteristics and uses a gravity model that presumes that countries closer to each other trade more with each other. Natural Openness (WEI) from Wei (2000) is based on country size, geography and linguistics. The benefit of using natural openness and openness measured by trade is that trade potentially includes trade policies.

I test if these characteristics are important for multinational firm excess value by repeating the tests presented in Table 3 for one characteristic at a time ${ }^{15}$ For each country characteristic, I compute the firm weighted average measure using the subsidiary asset weights as previously described. For example, multinational firm distance is the asset weighted bilateral distance between the UK and its overseas divisions. The results are presented in Table 7. The coefficients on GlobalDiv, GlobalDiv ${ }^{2}$, and the characteristic of interest $(Z)$ only are shown in the sake of brevity. First, I examine

\footnotetext{
${ }^{15}$ The country characteristics tend to be highly correlated, so that multicollinearity may make it difficult to assess the separate effects in regressions with multiple independent variables.
} 
geographical distance by including the natural logarithm of the asset weighted bilateral distance, measured in thousands of kilometers. The coefficient of -0.014 in regression (1) is statistically significant and indicates that the global diversification premium is negatively related to the average geographical distance between the UK parent and its subsidiaries. This result may follow because distance dampens multinational productivity (Barba Navaretti and Venables (2005)) and/or geographical distance may provide a barrier to monitoring of foreign divisions.

Next, I examine if the UK and host country have a common language or religion, and if the host country is a former British colony. The three characteristics are dummy variables equal to one if the host country has a common language with the UK (English), a common primary religion (Protestant), or is/was a British colony respectively. The results are presented in the columns (2) - (4) of Table 7. The global diversification premium is greater for multinational firms that have a greater proportion of foreign direct investment in host countries sharing the same primary language, same primary religion or are/were British colonies. Lastly, in columns (5) and (6) I report the results of estimations examining openness. The coefficients of both the Frankel and Romer and Wei measures of natural openness to trade are positive and significant, which reveals that the global diversification premium is larger where the host country is open to trade.

Overall, the findings on linkages between the global diversification value and distance, culture, and openness show that non-financial country-level characteristics play a role in financial outcomes; in this instance the ability for multinational firms to create value through FDI

\subsection{Alternative specifications}

\subsubsection{Global Diversification}

The measure of global diversification employed in the preceding results is the number of countries in which a multinational firm invests. It is possible that the diversification premium is associated with only this measure of diversification, or that an alternative measure of diversification adds better insight to the findings. Table 8 presents regression results using alternative measures of diversification. First, in regressions (1) and (2) the foreign asset weight and country weight Hirschman-Herfindahl (Country HHI) 
Index are employed as measures of global diversification. In both estimations, the coefficient on the alternate measure of global diversification is significant and implies a global diversification premium. However, the results in column (3) shows that number of countries in which a multinational firm invests better estimates the value premium

Columns (4) - (7) of Table 8 present robustness results for different types of diversification. In columns (4) and (5) the number of industries in which a firm invests (Ind Div) is employed as the measure of industrial diversification. The coefficients on Ind Div suggest an industrial diversification discount but the effect is insignificant. In column (5) the coefficient on global diversification continues to be significant. Results in column (6) show that organizational diversification, measured by subsidiary count, is significant in explaining value. However, given the high correlation between the number of subsidiaries and countries shown in Table 2 it is not surprising that subsidiary count ceases to be significant when combined with Global Div in column (7). Combined, these results confirm that the value premium is robust to the choice of measurement of diversification, and that the number of countries in which a multinational firm invests is not a proxy for alternative forms of diversification.

\subsection{Endogeneity}

Since multinational firms choose to diversify internationally, the same firm-level characteristics that guide this decision may also affect the market's valuation of the firm. As explored in the industrial diversification literature by Campa and Kedia (2002), Chevalier (2004), Graham et al. (2002), Lamont and Polk (2001), Maksimovic and Phillips (2002), Villalonga (2004a), Villalonga (2004b), Whited (2001) and others, failure to control for firm traits that drive the diversification decision may produce misleading econometric results that inappropriately attribute the premium to global diversification per se rather than to the underlying traits that induce firms to diversify overseas.

To control for multinational firm-specific traits and endogeneity concerns, two steps are taken. First, three instrumental variable specifications are used. The first instrumental variable specification uses industry effects. Industry factors may jointly explain global diversification and the global diversification premium because different production technologies and intellectual capital offer varying opportunities for global diversi- 
fication. If differences in firm characteristics do not fully capture the industry effects, then the premium may arise because UK firms in specific industries are both more valuable than their foreign comparable firms, and are more likely to diversify globally. The second instrumental variable specification additionally examines if multinational firm characteristics, and not differences from their imputed measures, affect diversification choice and valuation. For example, larger firms may be more likely to diversify overseas because they have created value in the UK. The third specification uses a tobit instrumental variable estimation to account for the left censoring in global diversification. This reflects that certain industries and firm characteristics may be unsuitable for global diversification. All instrumental variable results use two-stage least squares estimations, where the first stage regression estimates the degree of global diversification using the instruments. All two-stage least squares regressions include calendar-year effects, standard errors are clustered at the firm-level, and only the linear effect of diversification on value is included.

In all three specifications, the regression results continue to indicate a diversification premium for multinational firms. The first set of results that uses industry effects as instruments is presented in column (1) of Table 9. The coefficient of global diversification on excess value remains positive and significant. Unreported first stage regression results show that industry effects are important for global diversification choice. Specifically, energy and telecommunications firms are likely to most diversified while construction and electricity exhibit a negative association with diversification. The second specification additionally uses multinational firm level characteristics as instruments in the first stage. ${ }^{16}$ Regression (2) reports the results and confirms the finding of a global diversification premium. Finally the tobit instrumental variable regression results that use both industry and firm characteristics are presented in regression (3). As before the results support the evidence that global diversification is associated with a value premium.

The second step in controlling for endogeneity is to use Heckman's two-step proce-

\footnotetext{
${ }^{16}$ In the first stage regressions firm size and investment in R\&D are the most important determinants of global diversification.
} 
dure. The goal is to control for the self-selection bias due to firms' choosing to diversify internationally by incorporating the diversification decision formally into the econometric estimation. To employ Heckman's procedure the UK multinational firms are combined with the remaining FTSE 500 firms that are focused domestically. This results in a sample of 2,365 firm-years, of which 1,166 are internationally diversified. The first step estimates whether a firm is diversified internationally. This involves a probit estimation with a dependent dummy variable equal to one if the firm is a multinational firm and zero otherwise, where explanatory variables are the instrumental variables used in regressions (3) and (4). The second stage treats excess value as the dependent variable and yields estimates for the relationship between diversity and excess value and the self-selection model (Lambda).

Regression (4) of Table 9 presents the results. The results of the two-stage estimation of the endogenous self-selection model confirm the existence of a global diversification premium. In the excess value equation, global diversification enters positively and significantly, but is slightly lower compared with earlier results. The selection parameter, Lambda, is positive but insignificant. This suggests that firms with higher excess valuations are more likely to diversify but the effect is insignificant.

In summary, unlike for the findings on industrial diversification, simultaneity bias does not explain the global diversification premium. Further, the global diversification premium is robust to controlling for self-selection.

\section{Conclusion}

In this paper, I use detailed FDI data to shed new light on the nature of global diversification by multinational firms. Using a unique sample of $251 \mathrm{UK}$ multinational firms and 4,676 subsidiaries, the paper first shows that multinational firms exhibit, on average, a global diversification premium compared with a country-industry matched portfolio of focused firms. Second, I examine channels through which multinational firms can add value and show that the value premium is higher where the difference between the UK and subsidiary host country's firm-level corporate governance is highest; multinational firms are compensated for good corporate governance. 
Next, I examine whether internal capital markets contribute to the global diversification value premium. Stein (1997) argues that diversified firms can add value through engaging in "winner-picking" in internal capital markets. I estimate the value added by internal capital markets and find that the global diversification premium is positively related to the value added from transfers across divisions. This result does not rule out that agency costs of internal capital markets are prevalent (Shin and Stulz (1998), Rajan et al. (2000)), but that the premium is larger where the net effect is positive. Furthermore, the results show that the relation between the diversification premium and transfers across divisions is stronger in well-governed firms. Better governed multinational firms create more value through efficient transfers in their global internal capital market. In extensions to the main findings, I show that culture, distance, and openness play a role in explaining the global diversification premium. Additionally, the main results are robust to country-level differences, and alternative diversification and governance mechanisms. Further, the results continue to obtain in regressions controlling for endogeneity and self-selection.

The findings are consistent with the hypothesis that multinational firms' competitive advantages lead to higher valuations. Then, if shareholders have global diversification as an objective, investing in multinational firms is preferable over investing directly in foreign local firms. This offers insight into why global diversification has continued to increase, as documented both here and in Denis et al. (2002).

Future research should address better identification of the channels by which multinational firms can create value. Specifically, examining organizational structure, the methods in which multinational firms invest overseas, and the assets they target could all potentially shed light on the value premium. 


\section{References}

Aggarwal, R., Erel, I., Ferreira, M., Matos, P., 2011. Does governance travel around the world? evidence from institutional investors. Journal of Financial Economics 100, $154-181$.

Aggarwal, R., Erel, I., Stulz, R.M., Williamson, R., 2009. Differences in governance practices between U.S. and foreign firms: Measurement, causes, and consequences. Review of Financial Studies 22, 3131-3169.

Ahern, K., Daminelli, D., Fracassi, C., 2012. Lost in translation? the effect of cultural values on mergers around the world. Journal of Financial Economics Forthcoming. University of Michigan Working Paper.

Antras, P., Desai, M.A., Foley, C.F., 2009. Multinational firms, FDI flows and imperfect capital markets. Quarterly Journal of Economics 124, 1171-1219.

Barba Navaretti, G., Castellini, D., 2004. Investments abroad and peformance at home: Evidence from italian multinationals. CEPR Discussion Papers 4284.

Barba Navaretti, G., Venables, A.J., 2005. Multinational Firms in the World Economy. Princeton University Press.

Barro, R., McCleary, R.M., 2003. Religion and economic growth across countries. American Sociological Review 68, 760-781.

Benfratello, L., Sembenelli, A., 2006. Foreign ownership and productivity: Is the direction of causality so obvious? International Journal of Industrial Organization 24, $733-751$.

Berger, P.G., Ofek, E., 1995. Diversification's effect on firm value. Journal of Financial Economics 37, $39-65$.

Bodnar, G.M., Tang, C., Weintrop, J., 2005. Determinants of the value of multinationality. NBER Working Paper No. W6224. 
Campa, J.M., Kedia, S., 2002. Explaining the diversification discount. The Journal of Finance 57, 1731-1762.

Caves, R.E., 1996. Multinational Enterprise and Economic Analysis. Cambridge University Press, Cambridge, England.

Chevalier, J.A., 2004. What do we know about cross-subsidization? evidence from merging firms. Advances in Economic Analysis and Policy 4.

Christophe, S.E., Pfeiffer, Jr., R.J., 2002. The valuation of MNC international operations during the 1990s. Review of Quantitative Finance and Accounting 18, 119-138.

Claessens, S., Djankov, S., Fan, J., Lang, L., 2002. Disentangling the incentive and entrenchment effects of large shareholdings. Journal of Finance 57, 2741-2771.

Click, R.W., Harrison, P., 2000. Does multinationality matter? Evidence of value destruction in U.S. multinational corporations. Federal Reserve Board working paper.

Dastidar, P., 2009. International corporate diversification and performance: Does firm self-selection matter? Journal of International Business Studies 40, 71-85.

Denis, D.J., Denis, D.K., Sarin, A., 1997. Agency problems, equity ownership, and corporate diversification. The Journal of Finance 52, 135-160.

Denis, D.J., Denis, D.K., Yost, K., 2002. Global diversification, industrial diversification, and firm value. The Journal of Finance 57, 1951-1979.

Desai, M.A., Foley, C.F., Forbes, K., 2008a. Financial constraints and growth: Multinational and local firm responses to currency crises. Review of Financial Studies 21, 2857-2888.

Desai, M.A., Foley, C.F., Hines Jr., J.R., 2004a. Foreign direct investment in a world of multiple taxes. Journal of Public Economics 88, 2724-2744.

Desai, M.A., Foley, C.F., Hines Jr., J.R., 2004b. A multinational perspective on capital structure choice and internal capital markets. The Journal of Finance 59, 2451-2487. 
Desai, M.A., Foley, C.F., Hines Jr., J.R., 2005. Foreign direct investment and the domestic capital stock. The American Economic Review 95, 33.

Desai, M.A., Foley, C.F., Hines Jr., J.R., 2007. Dividend policy inside the multinational firm. Financial Management 36, 5-26.

Desai, M.A., Foley, C.F., Hines Jr., J.R., 2008b. Capital structure with risky foreign investment. Journal of Financial Economics 88, 534-553.

Dos Santos, M., Errunza, V., Miller, D., 2008. Does corporate international diversification destroy value? evidence from cross-border mergers and acquisitions. Journal of Banking and Finance 32, 2716-2724.

Doukas, J.A., Lang, L.H.P., 2003. Foreign direct investment, diversification and firm performance. Journal of International Business Studies 34, 153-172.

Dyck, A., Zingales, L., 2004. Private benefits of control: An international comparison. Journal of Finance 59, 533-596.

Ellis, J., Moeller, S.B., Schlingemann, F.P., Stulz, R.M., 2012. Globalization, governance, and the returns to cross-border acquisitions. Fisher College of Business WP 2012-03-003.

Fauver, L., Houston, J., Naranjo, A., 2003. Capital market development, international integration, legal systems, and the value of corporate diversification: A cross-country analysis. Journal of Financial and Quantitative Analysis 38, 135-157.

Frankel, J.A., Romer, D., 1999. Does trade create growth? American Economic Review 89, 379-399.

Gande, A., Schenzler, C., Senbet, L.W., 2009. Valuation effects of global diversification. Journal of International Business Studies 40, 1515-1532.

Graham, J.R., Lemmon, M.L., Wolf, J.G., 2002. Does corporate diversification destroy value? The Journal of Finance 57, 695-720. 
Griffith, R., 1999. Using the ard establishment level data to look at foreign ownership and productivity in the united kingdom. Economic Journal 109, 416-442.

Griffith, R., Redding, S., Simpson, H., 2004. Foreign ownership and productivity: New evidence from the service sector and the R\&D lab. Oxford Review of Economic Policy 20, 440-456.

Griffith, R., Simpson, H., 2004. Characteristics of foreign-owned firms on UK manufacturing productivity, in: Blundell, R., Card, D., Freeman, R.B. (Eds.), Creating a Premier League Economy. The University of Chicago Press, pp. 147-180.

Guiso, L., Sapienza, P., Zingales, L., 2003. People's opium? Religion and economic attitudes. Journal of Monetary Economics 50, 225-282.

Guiso, L., Sapienza, P., Zingales, L., 2006. Does culture affect economic outcomes? Journal of Economic Perspectives 20, 23-48.

Hoechle, D., Schmid, M., Walter, I., david Yermack, 2011. How much of the diversification discount can be explained by poor corporate governance? Journal of Financial Economics forthcoming.

Hymer, S., 1976. The International Operations of National Firms: A Study of Direct Foreign Investment. MIT Press, Cambridge, MA.

Jensen, M.C., Meckling, W.H., 1976. Theory of the firm: managerial behavior, agency costs, and ownership structure. Journal of Financial Economics 3, 305-360.

John, K., Ofek, E., 1995. Asset sales and increase in focus. Journal of Financial Economics 37, 105 - 126.

Khanna, T., Palepu, K., 2000. Is group affiliation profitable in emerging markets? an analysis of diversified indian business groups. Journal of Finance 55, 867-891.

La Porta, R., de Silanes, F.L., Shleifer, A., Vishny, R.W., 1998. Law and finance. The Journal of Political Economy 106, 1113-1155. 
La Porta, R., de Silanes, F.L., Shleifer, A., Vishny, R.W., 2000. Investor protection and corporate governance. Journal of Financial Economics 58, 3-27.

Lamont, O.A., Polk, C., 2001. The diversification discount: Cash flows versus returns. The Journal of Finance 56, 1693-1721.

Lang, L.H.P., Stulz, R.M., 1994. Tobin's $q$, corporate diversification, and firm performance. The Journal of Political Economy 102, 1248-1280.

Lins, K., Servaes, H., 1999. International evidence on the value of corporate diversification. The Journal of Finance 54, 2215-2239.

Maksimovic, V., Phillips, G., 2002. Do conglomerate firms allocate resources inefficiently across industries? theory and evidence. The Journal of Finance 57, 721-767.

Moeller, S.B., Schlingemann, F.P., 2005. Global diversification and bidder gains: A comparison between cross-border and domestic acquisitions. Journal of Banking and Finance 29, 533-564.

Morck, R., Shleifer, A., Vishny, R.W., 1990. Do managerial objectives drive bad acquisitions? The Journal of Finance 45, 31-48.

Morck, R., Yeung, B., 1991. Why investors value multinationality. The Journal of Business 64, 165-187.

Mueller, H., Philipon, T., 2011. Family firms and labor relations. American Economic Journal: Macroeconomics 3, 218-245.

Rajan, R., Servaes, H., Zingales, L., 2000. The cost of diversity: The diversification discount and inefficient investment. The Journal of Finance 55, 35-80.

Schoar, A., 2002. The effect of diversification on firm productivity. The Journal of Finance 62, 2379-2403.

Servaes, H., 1996. The value of diversification during the conglomerate merger wave. The Journal of Finance 51, 1201-1225. 
Shin, H.H., Stulz, R.M., 1998. Are internal capital markets efficient? Quarterly Journal of Economics 113, 531-552.

Stein, J.C., 1997. Internal capital markets and the competition for corporate resources. Journal of Finance 52, 111-133.

Stulz, R.M., Williamson, R., 2003. Culture, openness, and finance. Journal of Financial Economics 70, 313-349.

Tinbergen, J., 1962. Shaping the World Economy: Suggestions for an International Economic Policy. New York: The Twentieth Century Fund.

Villalonga, B., 2004a. Diversification discount or premium? New evidence from the business information tracking series. The Journal of Finance 59, 479-506.

Villalonga, B., 2004b. Does diversification cause the diversification discount? Financial Management 33, 5-27.

Wei, S.J., 2000. Natural openness and good government. Unpublished working paper no. 7765. NBER, Cambridge, MA.

Whited, T.M., 2001. Is it inefficient investment that causes the diversification discount? The Journal of Finance 56, 1667-1691. 
Table 1: Summary statistics of multinational firm investment and operations. Descriptive statistics of multinational firm investment and operations at the subsidiary level are presented in Panel A for all years and Panel B year by year. Subsidiaries is the number of subsidiaries, Global Div is the number of countries, and Ind Div is the number of industries in which a multinational firm invests in a giver year. Foreign Weight, European Weight, US Weight, and Asia Weight represent the percentage of assets multinational firms hold in all countries except the UK, Europe, the US, and Asia respectively. Subsidiary Ownership is the average ownership that a multinational firm holds in its subsidiaries.

\begin{tabular}{lcccc}
\hline Panel A: All years & & & & \\
\hline & Mean & Median & Total & Observations \\
\hline Subsidiaries & 18.3 & 8.0 & 21,315 & 1,166 \\
Global Div & 12.2 & 6.0 & 202 & 1,166 \\
Ind Div & 2.5 & 2.0 & 18 & 1,166 \\
Foreign Weight & $54.5 \%$ & $62.4 \%$ & - & 1,166 \\
European Weight & $17.9 \%$ & $6.2 \%$ & - & 1,166 \\
US Weight & $16.5 \%$ & $1.6 \%$ & - & 1,166 \\
Asia Weight & $1.7 \%$ & $0.0 \%$ & - & 1,166 \\
Subsidiary Ownership & $94.5 \%$ & $100.0 \%$ & - & 1,166 \\
\hline
\end{tabular}

\begin{tabular}{|c|c|c|c|c|c|c|c|c|}
\hline \multicolumn{9}{|l|}{ Panel B: Means by year } \\
\hline Year & 1999 & 2000 & 2001 & 2002 & 2003 & 2004 & 2005 & All Years \\
\hline Firms & 156 & 163 & 167 & 179 & 178 & 166 & 157 & 1,166 \\
\hline Subsidiaries & 18.1 & 17.6 & 19.4 & 19.4 & 19.8 & 17.8 & 15.4 & 18.3 \\
\hline Countries & 11.6 & 11.9 & 12.1 & 12.7 & 13.6 & 12.4 & 10.9 & 12.2 \\
\hline Industries & 2.8 & 2.7 & 2.6 & 2.5 & 2.6 & 2.4 & 2.2 & 2.5 \\
\hline Foreign Weight & $49.2 \%$ & $50.5 \%$ & $49.3 \%$ & $51.4 \%$ & $54.6 \%$ & $59.6 \%$ & $67.7 \%$ & $54.5 \%$ \\
\hline European Weight & $18.1 \%$ & $17.2 \%$ & $15.8 \%$ & $16.9 \%$ & $18.8 \%$ & $18.6 \%$ & $20.3 \%$ & $17.9 \%$ \\
\hline US Weight & $17.9 \%$ & $18.4 \%$ & $19.5 \%$ & $17.4 \%$ & $17.9 \%$ & $11.3 \%$ & $12.8 \%$ & $16.5 \%$ \\
\hline Asia Weight & $1.5 \%$ & $0.8 \%$ & $1.0 \%$ & $1.0 \%$ & $1.2 \%$ & $3.2 \%$ & $3.3 \%$ & $1.7 \%$ \\
\hline Subsidiary Ownership & 0.949 & 0.939 & 0.929 & 0.947 & 0.947 & 0.951 & 0.950 & 0.945 \\
\hline
\end{tabular}


Table 2: Summary statistics of excess Value and diversification. Panel A presents descriptive statistics of multinational firm excess value and relative firm characteristics. Excess value and relative firm characteristics for multinational firms are calculated as the difference between multinational firm values and a country-industry matched portfolio of focused foreign firms, using multinational firm asset weights from the ONS AFDI sample. Specifically, excess value is measured as the log difference in Tobin's q. Panel B presents correlation results of global, industrial and organizational (number of subsidiaries) diversification for multinational firms. Panel $\mathrm{C}$ shows multinational firm excess value conditioning in industrial and global diversification. $* * *(* *, *)$ denote significance at the $1 \%(5 \%, 10 \%)$ confidence level. The difference in medians is tested using the nonparametric 2-sample test on the equality of medians and Fisher's exact test.

\begin{tabular}{lcccc}
\hline \multicolumn{4}{l}{ Panel A: Excess value and firm characteristics } \\
\hline & Mean & Median & Std Dev & Obs \\
\hline Excess Value & $0.101 * * *$ & $0.060 * * *$ & 0.514 & 1,166 \\
Relative Debt/Assets & $(0.007)$ & $(0.019)$ & 0.237 & 1,166 \\
Relative Capex/Sales & $0.037 * * *$ & $(0.003)$ & 0.172 & 1,166 \\
Relative Ebit/Sales & $0.028 * * *$ & $0.011 * *$ & 0.097 & 1,166 \\
Relative R\&D/Sales & $0.007 * * *$ & 0.000 & 0.027 & 1,166 \\
Relative Sales & $0.529 * * *$ & $0.604 * * *$ & 1.610 & 1,166 \\
\hline
\end{tabular}

\begin{tabular}{lcc}
\hline Panel B: Diversification & \\
\hline & Countries & Industries \\
\hline Industries & $0.34^{* * *}$ & 1.00 \\
& 0.00 & \\
Subsidiaries & $0.86^{* * *}$ & $0.39 * * *$ \\
& 0.00 & 0.00 \\
\hline
\end{tabular}

\begin{tabular}{lcccc}
\hline \multicolumn{4}{l}{ Panel C: Diversification and excess value } \\
\hline \multicolumn{5}{l}{ Industries } \\
\hline \multirow{2}{*}{1} & 2 & {$[3,10)$} & $>10$ & ALL \\
\cline { 2 - 5 } 2 & $-0.088^{*}$ & $-0.100^{*}$ & $0.358^{* * *}$ & 0.038 \\
$>2$ & $-0.080^{* *}$ & $0.079 *$ & $0.305^{* * *}$ & $0.103 * * *$ \\
ALL & $0.075^{* *}$ & $0.077^{* *}$ & $0.196^{* * *}$ & $0.133^{* * *}$ \\
\hline
\end{tabular}


Table 3: Excess Value and global diversification. Each column presents estimates from a regression of excess value on measures of global diversification and relative firm-level characteristics. Excess value (relative firm-level characteristics) are calculated as the difference between the Tobin's q (firm characteristics) for the multinational firm and imputed Tobin's q (firm characteristics), where imputed values are calculated using median country-industry values in an asset-weighted country-industry matched replicating portfolio. Global diversification (Global Div) is measured as the number of countries in which a multinational firm invests in a given year. All regressions include multinational firm clustered standard errors and calendar-year dummies. $* * *(* *, *)$ denote significance at the $1 \%(5 \%, 10 \%)$ confidence level.

\begin{tabular}{|c|c|c|c|c|c|c|}
\hline & (1) & (2) & (3) & (4) & (5) & (6) \\
\hline Global Div & & $\begin{array}{c}0.008 * * * \\
(0.003)\end{array}$ & $\begin{array}{c}0.019 * * * \\
(0.004)\end{array}$ & & $\begin{array}{c}0.007 * * * \\
(0.002)\end{array}$ & $\begin{array}{c}0.018 * * * \\
(0.004)\end{array}$ \\
\hline Global Div ${ }^{2}$ & & & $\begin{array}{c}-1.77 \mathrm{e}-4 * * * \\
(5.08 \mathrm{e}-5)\end{array}$ & & & $\begin{array}{c}-1.71 \mathrm{e}-4 * * * \\
(4.28 \mathrm{e}-5)\end{array}$ \\
\hline Relative Debt/Assets & & & & $\begin{array}{c}0.120 \\
(0.123)\end{array}$ & $\begin{array}{c}0.072 \\
(0.117)\end{array}$ & $\begin{array}{c}0.094 \\
(0.116)\end{array}$ \\
\hline Relative Capex/Sales & & & & $\begin{array}{c}0.519 * * * \\
(0.196)\end{array}$ & $\begin{array}{c}0.500 * * * \\
(0.194)\end{array}$ & $\begin{array}{c}0.490 * * * \\
(0.184)\end{array}$ \\
\hline Relative Ebit/Sales & & & & $\begin{array}{c}0.972 * * * \\
(0.284)\end{array}$ & $\begin{array}{c}1.024 * * * \\
(0.280)\end{array}$ & $\begin{array}{c}1.058 * * * \\
(0.275)\end{array}$ \\
\hline Relative R\&D/Sales & & & & $\begin{array}{c}4.386 * * * \\
(1.095)\end{array}$ & $\begin{array}{c}3.719 * * * \\
(0.978)\end{array}$ & $\begin{array}{c}3.588 * * * \\
(0.963)\end{array}$ \\
\hline Relative $\log ($ Sales $)$ & & & & $\begin{array}{c}0.003 \\
(0.019)\end{array}$ & $\begin{array}{l}-0.017 \\
(0.019)\end{array}$ & $\begin{array}{l}-0.018 \\
(0.019)\end{array}$ \\
\hline Constant & $\begin{array}{c}0.153 * * * \\
(0.047)\end{array}$ & $\begin{array}{c}0.063 \\
(0.053)\end{array}$ & $\begin{array}{l}-0.007 \\
(0.056)\end{array}$ & $\begin{array}{c}0.110 * * \\
(0.044)\end{array}$ & $\begin{array}{c}0.018 \\
(0.050)\end{array}$ & $\begin{array}{l}-0.052 \\
(0.054)\end{array}$ \\
\hline Adj. R-Sq & 0.01 & 0.05 & 0.08 & 0.11 & 0.15 & 0.17 \\
\hline Obs & 1,166 & 1,166 & 1,166 & 1,166 & 1,166 & 1,166 \\
\hline
\end{tabular}


Table 4: Excess value, governance and global diversification. Each column presents estimates from a regression of excess value on measures of global diversification, relative firm-level characteristics and corporate governance. Excess value (relative firm-level characteristics) are calculated as in Table 3 and corporate governance is described in Section 3.2. GOV is the multinational parent composite governance index collected by Risk Metrics/ISS. GOV GAP represents the gap in composite governance index between the UK parent and a portfolio of country-industry matched benchmark firms. GOV GAP $\times$ OWN interacts GOV GAP with the percentage ownership that multinational firms have in subsidiaries. GOV $\mathrm{GAP} \times \mathrm{OWN}_{100}$ repeats this for only those subsidiaries in which multinational firms own one hundred percent. POS GOV GAP includes the GOV GAP for multinational firms with GOV GAP $>0$ and zero otherwise. All regressions include multinational firm clustered standard errors and year dummies. *** $(* *, *)$ denote significance at the $1 \%(5 \%, 10 \%)$ confidence level.

\begin{tabular}{|c|c|c|c|c|c|}
\hline & (1) & (2) & (3) & (4) & (5) \\
\hline Global Div & $\begin{array}{c}0.0154 * * * \\
(0.004)\end{array}$ & $\begin{array}{c}0.017 * * * \\
(0.004)\end{array}$ & $\begin{array}{c}0.017 * * * \\
(0.004)\end{array}$ & $\begin{array}{c}0.017 * * * \\
(0.004)\end{array}$ & $\begin{array}{c}0.015 * * * \\
(0.004)\end{array}$ \\
\hline Global Div ${ }^{2}$ & $\begin{array}{c}-0.0001 \\
(7.00 \mathrm{e}-5)\end{array}$ & $\begin{array}{c}-1.64 \mathrm{e}-4 * * * \\
(4.28 \mathrm{e}-5)\end{array}$ & $\begin{array}{c}-1.68 \mathrm{e}-4 * * * \\
(4.27 \mathrm{e}-5)\end{array}$ & $\begin{array}{c}-1.63 \mathrm{e}-4 * * * \\
(4.28 \mathrm{e}-5)\end{array}$ & $\begin{array}{c}-1.72 \mathrm{e}-4 * * * \\
(4.24 \mathrm{e}-5)\end{array}$ \\
\hline GOV & $\begin{array}{c}0.009 * * * \\
(0.002)\end{array}$ & & & & \\
\hline GOV GAP & & $\begin{array}{c}0.012 * * \\
(0.005)\end{array}$ & $\begin{array}{c}0.008 * * \\
(0.004)\end{array}$ & $\begin{array}{c}0.008 * * \\
(0.004)\end{array}$ & \\
\hline GOV GAP $\times$ OWN & & & $\begin{array}{c}0.010 * * \\
(0.004)\end{array}$ & & \\
\hline OWN & & & $\begin{array}{l}1.593 \mathrm{e}-4 \\
(5.83 \mathrm{e}-4)\end{array}$ & & \\
\hline Global Div $\times$ GOV GAP & & & & $\begin{array}{c}0.001 * * * \\
(0.0003)\end{array}$ & \\
\hline POS GOV GAP & & & & & $\begin{array}{c}0.014 * * * \\
(0.007)\end{array}$ \\
\hline Relative Debt/Assets & $\begin{array}{c}0.082 \\
(0.124)\end{array}$ & $\begin{array}{c}0.105 \\
(0.115)\end{array}$ & $\begin{array}{c}0.103 \\
(0.116)\end{array}$ & $\begin{array}{c}0.108 \\
(0.115)\end{array}$ & $\begin{array}{c}0.102 \\
(0.116)\end{array}$ \\
\hline Relative Capex/Sales & $\begin{array}{c}0.138 \\
(1.075)\end{array}$ & $\begin{array}{c}0.528 * * * \\
(0.176)\end{array}$ & $\begin{array}{c}0.511 * * * \\
(0.182)\end{array}$ & $\begin{array}{c}0.532 * * * \\
(0.175)\end{array}$ & $\begin{array}{c}0.516^{* * * *} \\
(0.178)\end{array}$ \\
\hline Relative Ebit/Sales & $\begin{array}{c}1.748 * * * \\
(0.345)\end{array}$ & $\begin{array}{c}1.034 * * * \\
(0.270)\end{array}$ & $\begin{array}{c}1.034 * * * \\
(0.274)\end{array}$ & $\begin{array}{c}1.025 * * * \\
(0.270)\end{array}$ & $\begin{array}{c}1.036 * * * \\
(0.274)\end{array}$ \\
\hline Relative R\&D/Sales & $\begin{array}{c}2.995 * * * \\
(0.994)\end{array}$ & $\begin{array}{c}3.473 * * * \\
(0.916)\end{array}$ & $\begin{array}{c}3.497 * * * \\
(0.937)\end{array}$ & $\begin{array}{c}3.435 * * * \\
(0.917)\end{array}$ & $\begin{array}{c}3.503 * * * \\
(0.956)\end{array}$ \\
\hline Relative $\log ($ Sales $)$ & $\begin{array}{l}-0.041 * \\
(0.022)\end{array}$ & $\begin{array}{l}-0.022 \\
(0.018)\end{array}$ & $\begin{array}{l}-0.021 \\
(0.019)\end{array}$ & $\begin{array}{l}-0.023 \\
(0.018)\end{array}$ & $\begin{array}{l}-0.018 \\
(0.018)\end{array}$ \\
\hline Constant & $\begin{array}{c}-4.065 * * * \\
(1.470)\end{array}$ & $\begin{array}{l}-0.037 \\
(0.055)\end{array}$ & $\begin{array}{l}-0.040 \\
(0.055)\end{array}$ & $\begin{array}{l}-0.035 \\
(0.055)\end{array}$ & $\begin{array}{l}-0.060 \\
(0.055)\end{array}$ \\
\hline Adj. R-Sq & 0.26 & 0.18 & 0.17 & 0.18 & 0.17 \\
\hline Obs & 1,166 & 1,166 & 1,166 & 1,166 & 1,166 \\
\hline
\end{tabular}


Table 5: The efficiency of internal capital markets. Panel A presents descriptive statistics for valued added (VA). Value added measures the value created through transfers - in terms of investment weights towards higher productivity subsidiaries. Panel B presents descriptive statistics from sorts valued added first by global diversification (Global Div), and second by corporate governance (GOV). Panel C presents descriptive statistics from two-way sorts on global diversification (Global Div) and corporate governance (GOV). *** $(* *, *)$ denote significance at the $1 \%(5 \%, 10 \%)$ confidence level.

\begin{tabular}{|c|c|c|c|c|}
\hline \multicolumn{5}{|c|}{ Panel A: Value added descriptive statistics } \\
\hline & Mean & Median & Std Dev & Obs \\
\hline Value Added (VA) & $0.054 * * *$ & $0.063 * * *$ & 0.193 & 1,166 \\
\hline \multicolumn{5}{|c|}{ Panel B: Value added two-way splits } \\
\hline & Mean & Standard Error & Std Dev & Obs \\
\hline Global Div (Low) & 0.052 & 0.008 & 0.198 & 604 \\
\hline Global Div (High) & 0.074 & 0.008 & 0.187 & 562 \\
\hline High-Low & $0.022 * *$ & & & \\
\hline GOV (Low) & 0.043 & 0.0105 & 0.183 & 478 \\
\hline GOV (High) & 0.070 & 0.009 & 0.206 & 688 \\
\hline High-Low & $0.027 * *$ & & & \\
\hline \multicolumn{5}{|c|}{ Panel C: Value added four-way splits } \\
\hline Global Div & $\begin{array}{l}\text { GOV } \\
\text { (Low) }\end{array}$ & $\begin{array}{c}\text { GOV } \\
\text { (High) }\end{array}$ & Difference & \\
\hline (Low) & 0.046 & 0.045 & -0.001 & \\
\hline (High) & 0.038 & 0.088 & $0.050 * * *$ & \\
\hline Difference & -0.008 & $0.043 * * *$ & $0.051 * * *$ & \\
\hline
\end{tabular}


Table 6: Value and the efficiency of internal capital markets. Each column presents estimates from a regression of value on measures of global diversification, relative firm-level characteristics, value added and corporate governance. Value is measured as Tobin's q. Value added (VA) is the asset-weighted value added from internal capital market transfers across subsidiaries within a multinational firm. GOV is the multinational parent composite governance index collected by Risk Metrics/ISS. All regressions include multinational firm clustered standard errors and year dummies. *** (**,*) denote significance at the $1 \%$ $(5 \%, 10 \%)$ confidence level.

\begin{tabular}{|c|c|c|c|c|}
\hline & (1) & (2) & (3) & (4) \\
\hline Global Div & & $\begin{array}{c}0.031 * * * \\
(0.005)\end{array}$ & $\begin{array}{c}0.023 * * * \\
(0.006)\end{array}$ & $\begin{array}{c}0.022 * * * \\
(0.006)\end{array}$ \\
\hline Global Div ${ }^{2}$ & & $\begin{array}{c}-0.0003 * * * \\
(0.0001)\end{array}$ & $\begin{array}{l}-0.0001 \\
(0.0001)\end{array}$ & $\begin{array}{l}-0.0001 \\
(0.0001)\end{array}$ \\
\hline VA & $\begin{array}{l}0.284 * \\
(0.168)\end{array}$ & $\begin{array}{l}0.280^{*} \\
(0.164)\end{array}$ & $\begin{array}{c}0.373 * * \\
(0.181)\end{array}$ & $\begin{array}{c}0.207 * * * \\
(0.170)\end{array}$ \\
\hline GOV & & & $\begin{array}{c}0.008 * * * \\
(0.002)\end{array}$ & $\begin{array}{c}0.007 * * * \\
(0.002)\end{array}$ \\
\hline $\mathrm{GOV} \times \mathrm{VA}$ & & & & $\begin{array}{c}0.003 * * * \\
(0.001)\end{array}$ \\
\hline Debt/Assets & $\begin{array}{c}0.287 * * \\
(0.140)\end{array}$ & $\begin{array}{c}0.141 \\
(0.140)\end{array}$ & $\begin{array}{c}0.046 \\
(0.161)\end{array}$ & $\begin{array}{c}0.046 \\
(0.162)\end{array}$ \\
\hline Capex/Sales & $\begin{array}{c}1.267 * * * \\
(0.190)\end{array}$ & $\begin{array}{c}1.209 * * * \\
(0.186)\end{array}$ & $\begin{array}{c}1.338 * * * \\
(0.249)\end{array}$ & $\begin{array}{c}1.338 * * * \\
(0.248)\end{array}$ \\
\hline EBIT/Sales & $\begin{array}{c}2.034 * * * \\
(0.330)\end{array}$ & $\begin{array}{c}2.058 * * * \\
(0.324)\end{array}$ & $\begin{array}{c}3.614 * * * \\
(0.428)\end{array}$ & $\begin{array}{c}3.614 * * * \\
(0.429)\end{array}$ \\
\hline R\&D/Sales & $\begin{array}{c}10.519 * * * \\
(1.075)\end{array}$ & $\begin{array}{c}8.796 * * * \\
(1.081)\end{array}$ & $\begin{array}{c}7.464 * * * \\
(1.110)\end{array}$ & $\begin{array}{c}7.462 * * * \\
(1.109)\end{array}$ \\
\hline Log(Sales) & $\begin{array}{l}-0.018 \\
(0.023)\end{array}$ & $\begin{array}{c}-0.078 * * * \\
(0.024)\end{array}$ & $\begin{array}{c}-0.092 * * * \\
(0.030)\end{array}$ & $\begin{array}{c}-0.092 * * * \\
(0.030)\end{array}$ \\
\hline Constant & $\begin{array}{c}2.186 * * * \\
(0.323)\end{array}$ & $\begin{array}{c}2.783 * * * \\
(0.330)\end{array}$ & $\begin{array}{c}-5.030 * * * \\
(1.867)\end{array}$ & $\begin{array}{c}-5.030 * * * \\
(1.867)\end{array}$ \\
\hline R-squared & 0.16 & 0.19 & 0.24 & 0.24 \\
\hline Observations & 1,166 & 1,166 & 1,166 & 1,166 \\
\hline
\end{tabular}


Table 7: Distance, culture and openness. Each column presents estimates from a regression of excess value on measures of global diversification, distance, culture and openness. The table shows only the coefficients of interest. All explanatory variables are estimated at the multinational parent level based on subsidiary location. Distance measures the asset-weighted distance between the UK and a multinational firm's subsidiaries. Language, Religion and Colony are asset-weighted dummy variables indicating if subsidiary host countries share a common language, common religion and are/were a British colony respectively. Natural Openness (FR) and Natural Openness (WEI) are asset-weighted measures of the openness of subsidiary host countries. Control variables shown in Table 3 are included but not presented. All regressions include multinational firm clustered standard errors and year dummies. *** (**,*) denote significance at the $1 \%(5 \%, 10 \%)$ confidence level.

\begin{tabular}{ccccccc}
\hline & $(1)$ & $(2)$ & $(3)$ & $(4)$ & $(5)$ & $(6)$ \\
\hline & Distance & Language & Religion & Colony & $\begin{array}{c}\text { Natural } \\
\text { Openness } \\
(\mathrm{FR})\end{array}$ & $\begin{array}{c}\text { Natural } \\
\text { Openness } \\
(\mathrm{WEI})\end{array}$ \\
\hline Global Div & $0.017 * * *$ & $0.017 * * *$ & $0.015^{* * *}$ & $0.017 * * *$ & $0.016^{* * *}$ & $0.018^{* * *}$ \\
& $(0.003)$ & $(0.003)$ & $(0.003)$ & $(0.003)$ & $(0.003)$ & $(0.003)$ \\
Global Div ${ }^{2}$ & $-1.24 \mathrm{e}-4 * * *$ & $-1.24 \mathrm{e}-4 * * *$ & $-1.02 \mathrm{e}-4 * * *$ & $-1.23 \mathrm{e}-4 * * *$ & $-1.11 \mathrm{e}-4 * * *$ & $-1.20 \mathrm{e}-4 * * *$ \\
& $(5.70 \mathrm{e}-5)$ & $(4.78 \mathrm{e}-5)$ & $(4.64 \mathrm{e}-5)$ & $(4.78 \mathrm{e}-5)$ & $(4.71 \mathrm{e}-5)$ & $(4.73 \mathrm{e}-5)$ \\
$\mathrm{Z}$ & $-0.0136 * *$ & $-0.184 * * *$ & $-0.142^{* * *}$ & $-0.166^{* * * *}$ & $0.006 * *$ & $0.187 * * *$ \\
& $(0.0072)$ & $(0.049)$ & $(0.058)$ & $(0.049)$ & $(0.002)$ & $(0.071)$ \\
\hline
\end{tabular}


Table 8: Excess value and global diversification: alternate diversification measures. Each column presents estimates from a regression of excess value on measures of diversification and relative firmlevel characteristics. The table shows only the coefficients of interest. Excess value (relative firm-level characteristics) are calculated as in Table 3. Global diversification (Global Div) is measured as the the percentage of total assets that a multinational firm has invested in foreign subsidiaries (Foreign Weight), and the multinational firm country asset weight Herfindahl-Hirschman index (Country HHI). Industrial diversification is measured as the number of industries in which a multinational firm invests (Ind Div), and industry asset weight Herfindahl-Hirschman index (Country HHI). Organizational diversification is measured as the number of subsidiaries through which a multinational firm invests (Subsidiaries). Control variables shown in Table 3 are included but not presented. All regressions include multinational firm clustered standard errors and year dummies. $* * *(* *, *)$ denote significance at the $1 \%(5 \%, 10 \%)$ confidence level.

\begin{tabular}{|c|c|c|c|c|c|c|c|}
\hline & \multicolumn{3}{|c|}{$\begin{array}{c}\text { Global } \\
\text { Diversification }\end{array}$} & \multicolumn{2}{|c|}{$\begin{array}{c}\text { Industrial } \\
\text { Diversification }\end{array}$} & \multicolumn{2}{|c|}{$\begin{array}{l}\text { Organizational } \\
\text { Diversification }\end{array}$} \\
\hline & (1) & (2) & (3) & (4) & (5) & (6) & (7) \\
\hline Global Div & & & $\begin{array}{c}0.017 * * * \\
(0.004)\end{array}$ & & $\begin{array}{c}0.019 * * * \\
(0.005)\end{array}$ & & $\begin{array}{c}0.021 * * * \\
(0.005)\end{array}$ \\
\hline Global Div ${ }^{2}$ & & & $\begin{array}{c}-1.64 \mathrm{e}-4 * * * \\
(4.41 \mathrm{e}-5)\end{array}$ & & $\begin{array}{c}-1.73 \mathrm{e}-4 * * * \\
(4.65 \mathrm{e}-5)\end{array}$ & & $\begin{array}{c}-1.79 \mathrm{e}-4^{* * * *} \\
(4.56 \mathrm{e}-5)\end{array}$ \\
\hline Foreign Weight & $\begin{array}{l}0.118 * \\
(0.071)\end{array}$ & & $\begin{array}{l}-0.003 \\
(0.086)\end{array}$ & & & & \\
\hline Country HHI & & $\begin{array}{c}-0.295 * * * \\
(0.0996)\end{array}$ & $\begin{array}{c}-0.030 \\
(0.1420)\end{array}$ & & & & \\
\hline Ind Div & & & & $\begin{array}{l}-0.007 \\
(0.019)\end{array}$ & $\begin{array}{l}-0.009 \\
(0.020)\end{array}$ & & \\
\hline Subsidiaries & & & & & & $\begin{array}{c}0.003 * * * \\
(0.001)\end{array}$ & $\begin{array}{l}-0.002 \\
(0.002)\end{array}$ \\
\hline
\end{tabular}


Table 9: Excess value and global diversification: endogeneity. Each column presents estimates from a regression of excess value on measures of global diversification and relative firm-level characteristics. Regressions (1) and (2) show results from two stage least squares instrumental variable regressions, where excess value and global diversification are instrumented in first stage regressions. Specifications for the first stage regression for global diversification are presented in the bottom panel. Regression (3) presents results from a instrumental variable tobit regression. Regression (4) presents results from a Heckman selfselection estimation, where global diversification is estimated using a sample of internationally diversified and focused firms. All regressions include multinational firm clustered standard errors and year dummies. $* * *(* *, *)$ denote significance at the $1 \%(5 \%, 10 \%)$ confidence level.

\begin{tabular}{|c|c|c|c|c|}
\hline & (1) & (2) & (3) & (4) \\
\hline & 2SLS & 2SLS & IVTOBIT & $\begin{array}{c}\text { Heckman } \\
\text { Self-selection }\end{array}$ \\
\hline Global Div & $\begin{array}{c}0.009 * * * \\
(0.002)\end{array}$ & $\begin{array}{c}0.009 * * * \\
(0.002)\end{array}$ & $\begin{array}{c}0.010 * * * \\
(0.002)\end{array}$ & $\begin{array}{c}0.007 * * * \\
(0.002)\end{array}$ \\
\hline Relative Debt/Assets & $\begin{array}{c}0.063 \\
(0.064)\end{array}$ & $\begin{array}{c}0.060 \\
(0.064)\end{array}$ & $\begin{array}{c}0.058 \\
(0.064)\end{array}$ & $\begin{array}{c}0.075 \\
(0.116)\end{array}$ \\
\hline Relative Capex/Sales & $\begin{array}{c}0.507 * * * \\
(0.086)\end{array}$ & $\begin{array}{c}0.507 * * * \\
(0.086)\end{array}$ & $\begin{array}{c}0.506^{* * * *} \\
(0.085)\end{array}$ & $\begin{array}{c}0.512 * * * \\
(0.195)\end{array}$ \\
\hline Relative Ebit/Sales & $\begin{array}{c}1.034 * * * \\
(0.151)\end{array}$ & $\begin{array}{c}1.037 * * * \\
(0.151)\end{array}$ & $\begin{array}{c}1.040 * * * \\
(0.150)\end{array}$ & $\begin{array}{c}1.011 * * * \\
(0.275)\end{array}$ \\
\hline Relative R\&D/Sales & $\begin{array}{c}3.591 * * * \\
(0.566)\end{array}$ & $\begin{array}{c}3.551 * * * \\
(0.563)\end{array}$ & $\begin{array}{c}3.515 * * * \\
(0.566)\end{array}$ & $\begin{array}{c}3.750 * * * \\
(0.983)\end{array}$ \\
\hline Relative $\log ($ Sales $)$ & $\begin{array}{l}-0.021 * \\
(0.011)\end{array}$ & $\begin{array}{c}-0.022 * * \\
(0.011)\end{array}$ & $\begin{array}{l}-0.022 * \\
(0.011)\end{array}$ & $\begin{array}{l}-0.016 \\
(0.019)\end{array}$ \\
\hline Constant & $\begin{array}{l}-0.006 \\
(0.047)\end{array}$ & $\begin{array}{l}-0.001 \\
(0.047)\end{array}$ & $\begin{array}{l}-0.051 \\
(0.042)\end{array}$ & $\begin{array}{c}0.011 \\
(0.049)\end{array}$ \\
\hline Adj. R-Sq & 0.15 & 0.14 & - & - \\
\hline Obs & 1,166 & 1,166 & 1,166 & 2,365 \\
\hline Lambda & & & & 0.029 \\
\hline \multicolumn{5}{|c|}{ Specification and Instruments } \\
\hline Industry Dummies & Yes & Yes & Yes & Yes \\
\hline Characteristics & No & Yes & Yes & Yes \\
\hline Year & Yes & Yes & Yes & Yes \\
\hline
\end{tabular}

